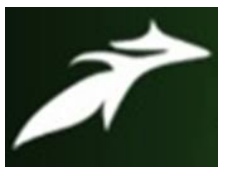

Awantika Rai et al, International Journal of Advances in Agricultural Science and Technology,

Vol.8 Issue.1, January-2021, pg. 33-39

ISSN: 2348-1358

Impact Factor: 6.057

NAAS Rating: 3.77

\title{
Knowledge of the Farmers towards the Improved Production Practices of Jowar in Ghazipur District of Uttar Pradesh
}

\author{
Awantika Rai*1; Prof. and Head (Dr.) Jahanara ${ }^{2}$ \\ Department of Agricultural Extension and Communication, Naini Agriculture Institiute, \\ Sam Higginbottom University of Agriculture Technology and Sciences, Prayagraj-211007 \\ DOI: 10.47856/ijaast.2021.v08i1.005
}

\begin{abstract}
The present study was conducted in UTTAR PRADESH state during the year 2019-2020 to assess the knowledge and adoption of farmers about improved production practices of Jowar and to find out the relationship with socio- economic characteristics of farmers about improved production practices of Jowar. Total 120 farmers were randomly selected from 10 villages from Ghazipursadar block of Ghazipur district. The descriptive research design was used for the study. The findings of the study revealed that 47.5 per cent of the respondents had medium level of knowledge about improved production practices of Jowar followed by high 20.33 per cent and low 31.66 per cent level of knowledge. Variables such as Farming experience, Risk orientation, Market orientation, Social Participation, Land holding and annual income at 0.05 level of significance whereas education and economic motivation at 0.01 level of significance.
\end{abstract}

KEYWORDS: Socio-economic, Knowledge, Improved Practices, Correlation, Jowar

${ }^{1}$ PG Student* (awantikarai94@gmail.com), ${ }^{2}$ Professor and Head (Dr.) Miss Jahanara

\section{INTRODUCTION}

Agriculture is the science and art of cultivating plants and live-stock we often hear that India is an agricultural country. This is basically means that agriculture is an important part of our livelihood. In India , agriculture is our primary economic activity and about two- third of our population is engaged in the same, you can consider farming to be rather a complete system which includes inputs, processing, and outputs. Sorghum (Sorghumbicolour) popularly known as "Jowar" is the most important food and fodder crop of dryland agriculture .The cereal crop is perennial in nature and possessing corn like leaves and bearing the grain in compact cluster. Jowar is the fifth most important crop after wheat, rice, maize and barley. It is found in the arid, semi arid parts due to its feature of being extremely drought tolerant 


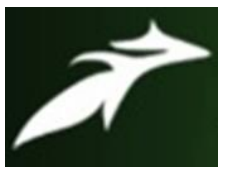

Awantika Rai et al, International Journal of Advances in Agricultural Science and Technology, Vol.8 Issue.1, January-2021, pg. 33-39

ISSN: 2348-1358

Impact Factor: 6.057

NAAS Rating: 3.77

\section{RESEARCH METHODOLOGY}

The present investigation is conducted in Ghazipur district of UTTAR PRADESH during the year 2019- 2020.Ghazipur district was selected purposively because of its adequate concentration of Jowar growers. There is 16 blocks in Ghazipur district out of that Ghazipursadar block was selected purposively.

There is 69 village in Ghazipursadar block. Out of these 10 village were selected randomly for the present study on the basis of maximum area covered under Jowar crop.

From the selected village a list of 120 farmers were prepared based on the farmers having knowledge about all the farming technique related to Jowar. The primary data was collected with the help of pre- structured interview schedule, designed especially in the light of objectives, whereas secondary data was collected from sources like thesis, journals, literature etc. It is conceived that the dependent variable knowledge was influenced by the independent variables like age, education, family type, farming experience, risk preference, economic motivation, annual income, social participation. The statistical measure like frequency, percentage and correlation were used to analyze the data to draw logical conclusion.

\section{RESULT AND DISCUSSION}

Socio-economic profile of the respondent: Socio-economic characteristics of the respondents were analyzed and presented in Table 1. Results show that majority (49.16\%) of the farmers belonged to middle age group followed by old age 32.5 per cent and young age 18. 33 per cent group. Padekar (2004) quoted similar findings. The frequency distribution was highly skewed towards low 43.33 per cent can only read and write while medium 45.00 per cent had knowledge upto high school followed by 11.66 per cent had knowledge upto higher secondary or above. stated similar findings. It is stated that 36.66 per cent had medium family size followed by small 31.66 per cent and large 31.66 per cent of family size. Majority (45.00\%) of the respondents had low annual income followed by medium 33.33 per cent and high 21.66 per cent of annual income. 


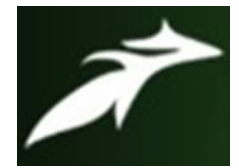

Awantika Rai et al, International Journal of Advances in Agricultural Science and Technology, Vol.8 Issue.1, January-2021, pg. 33-39

ISSN: 2348-1358

Impact Factor: 6.057

NAAS Rating: 3.77

Table-1:Sailent features of socio- economic profile of the respondents $(n=120)$

\begin{tabular}{|c|c|c|c|c|}
\hline Sr. No. & Variables & Category & Frequency & Percentage \\
\hline \multirow{3}{*}{1.} & \multirow{3}{*}{ Age } & young(upto 35) & 48 & 18.33 \\
\hline & & middle(35 to 55$)$ & 37 & 49.16 \\
\hline & & old(55 andabove) & 35 & 32.5 \\
\hline \multirow{3}{*}{2.} & \multirow{3}{*}{ Education } & Low & 52 & 43.33 \\
\hline & & Medium & 54 & 45.00 \\
\hline & & High & 14 & 11.66 \\
\hline \multirow{3}{*}{3.} & \multirow{3}{*}{ Family size } & Low & 38 & 31.66 \\
\hline & & Medium & 44 & 36.66 \\
\hline & & High & 38 & 31.66 \\
\hline \multirow{3}{*}{4.} & \multirow{3}{*}{ Annual income } & Low & 54 & 45.00 \\
\hline & & Medium & 40 & 33.33 \\
\hline & & High & 26 & 21.66 \\
\hline \multirow{3}{*}{5.} & \multirow{3}{*}{ Landholding } & Low(1-2 ha) & 65 & 54.16 \\
\hline & & Medium (2-3 ha) & 42 & 35.00 \\
\hline & & High (3 ha and above) & 13 & 10.83 \\
\hline \multirow{3}{*}{6.} & \multirow{3}{*}{ Social participation } & Low & 28 & 23.33 \\
\hline & & Medium & 86 & 71.66 \\
\hline & & High & 6 & 5.00 \\
\hline \multirow{3}{*}{7.} & \multirow{3}{*}{ Market orientation } & Low & 28 & 23.33 \\
\hline & & Medium & 52 & 43.33 \\
\hline & & High & 40 & 33.33 \\
\hline \multirow{3}{*}{8.} & \multirow{3}{*}{$\begin{array}{l}\text { Economic } \\
\text { Motivation }\end{array}$} & Low & 52 & 43.33 \\
\hline & & Medium & 55 & 45.83 \\
\hline & & High & 13 & 10.83 \\
\hline \multirow{3}{*}{9.} & \multirow{3}{*}{ Farming experience } & Low & 10 & 8.33 \\
\hline & & Medium & 56 & 46.66 \\
\hline & & High & 54 & 45.00 \\
\hline \multirow{3}{*}{10.} & \multirow{3}{*}{ Risk orientation } & Low & 10 & 8.33 \\
\hline & & Medium & 61 & 50.83 \\
\hline & & High & 49 & 40.83 \\
\hline
\end{tabular}

From the above table it was concluded that majority (54.16\%) of the respondents were small farmers (1to $2 \mathrm{ha}$ ), 35.00 per cent were medium farmers ( $2-5 \mathrm{ha}$ ), and 10.83 per cent were large farmers (5 ha and above). Kharmale (2006) quoted similar findings. Majority (71.66 \%) of the respondents were low in social participation comprises of 23.33 per cent medium and 5.00 per cent 


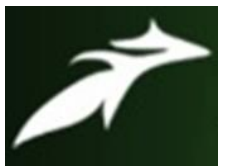

Awantika Rai et al, International Journal of Advances in Agricultural Science and Technology, Vol.8 Issue.1, January-2021, pg. 33-39

ISSN: 2348-1358

Impact Factor: 6.057

NAAS Rating: 3.77

low in social participation Sonsale(2000),Zote(2001),Borse(2002) stated similar findings. 43.33 per cent of the respondents were belonging medium market orientation whereas 23.33 per cent were low and 33.33 per cent were high in market orientation. Kadam (2002), Kumbhar (2003) extracted similar findings 10.83 per cent of the respondents were high in economic motivation ,45.83 per cent of the respondents were belonging to medium and 43.33 per cent were low in economic motivation. Darekar (2002) given similar findings46.66 per cent of the respondents were medium in farming experience, whereas as 45.00 were high in farming experience and 8.33 per cent were low in economic motivation. Bhagwat (2003), Ekatpure(2007) quoted similar findings Majority (50.83\%) of the respondents were belonging to medium risk orientation , whereas 40.83 per cent were of high risk orientation and 8.33 per cent were low in risk orientation. Zote(2001), Mane (2001) given similar findings.

Table-2: Knowledge of the respondents towards improved production practices of Jowar $(n=120)$

\begin{tabular}{|c|c|c|c|c|}
\hline Sr. No. & Variables & Category & Frequency & Percentage \\
\hline \multirow[t]{3}{*}{1.} & \multirow[t]{3}{*}{ Knowledge about storage of grain } & Low & 66 & 55.00 \\
\hline & & medium & 23 & 19.1 \\
\hline & & High & 31 & 25.8 \\
\hline \multirow[t]{3}{*}{2.} & \multirow[t]{3}{*}{ Knowledge about spacing } & Low & 42 & 35.00 \\
\hline & & Medium & 58 & 48.3 \\
\hline & & High & 20 & 16.66 \\
\hline \multirow[t]{3}{*}{3.} & \multirow[t]{3}{*}{ Knowledge about sowing time } & Low & 34 & 28.3 \\
\hline & & Medium & 64 & 53.3 \\
\hline & & High & 22 & 18.3 \\
\hline \multirow[t]{3}{*}{4.} & \multirow{3}{*}{$\begin{array}{l}\text { Knowledge about seed and its } \\
\text { treatment }\end{array}$} & Low & 34 & 28.33 \\
\hline & & Medium & 53 & 44.1 \\
\hline & & High & 33 & 27.5 \\
\hline \multirow[t]{3}{*}{5.} & \multirow[t]{3}{*}{ Knowledge about improved variety } & Low & 30 & 25.00 \\
\hline & & Medium & 51 & 42.5 \\
\hline & & High & 39 & 32.5 \\
\hline \multirow[t]{3}{*}{6.} & \multirow[t]{3}{*}{ Knowledge about field preparation } & Low & 66 & 55.00 \\
\hline & & Medium & 23 & 19.1 \\
\hline & & High & 31 & 25.83 \\
\hline \multirow[t]{2}{*}{7.} & \multirow{2}{*}{$\begin{array}{l}\text { Knowledg about manure and } \\
\text { fertilizers }\end{array}$} & Low & 40 & 33.33 \\
\hline & & Medium & 55 & 45.83 \\
\hline
\end{tabular}




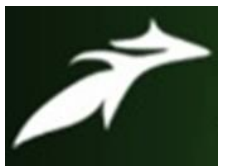

Awantika Rai et al, International Journal of Advances in Agricultural Science and Technology, Vol.8 Issue.1, January-2021, pg. 33-39

ISSN: 2348-1358

Impact Factor: 6.057

NAAS Rating: 3.77

\begin{tabular}{|c|c|c|c|c|}
\hline & & High & 25 & 20.83 \\
\hline \multirow[t]{3}{*}{8.} & \multirow[t]{3}{*}{ Knowledge about irrigation } & Low & 30 & 25.00 \\
\hline & & Medium & 65 & 54.16 \\
\hline & & High & 25 & 20.83 \\
\hline \multirow[t]{3}{*}{9.} & \multirow{3}{*}{$\begin{array}{l}\text { Knowledge about weeding and } \\
\text { hoeing operations }\end{array}$} & Low & 37 & 30.83 \\
\hline & & Medium & 58 & 48.33 \\
\hline & & High & 22 & 18.33 \\
\hline \multirow[t]{3}{*}{10.} & \multirow[t]{3}{*}{ Knowledge about weed control } & Low & 20 & 16.66 \\
\hline & & Medium & 55 & 45.8 \\
\hline & & High & 35 & 29.16 \\
\hline \multirow[t]{3}{*}{11.} & \multirow{3}{*}{$\begin{array}{l}\text { Knowledge about plant protection } \\
\text { measure }\end{array}$} & Low & 29 & 24.1 \\
\hline & & Medium & 63 & 52.5 \\
\hline & & High & 28 & 23.3 \\
\hline \multirow[t]{3}{*}{12.} & \multirow[t]{3}{*}{ Knowledge about harvesting } & Low & 27 & 22.5 \\
\hline & & Medium & 59 & 49.16 \\
\hline & & High & 34 & 28.33 \\
\hline \multirow[t]{3}{*}{13.} & \multirow{3}{*}{$\begin{array}{l}\text { Knowledge about threshing and } \\
\text { winnowing }\end{array}$} & Low & 41 & 34.16 \\
\hline & & Medium & 52 & 43.33 \\
\hline & & High & 27 & 22.5 \\
\hline
\end{tabular}

The above table shows that majority (55\%) of the respondents were having low knowledge about storage of grain, 19.1 per cent medium and 25.8 per cent respondents were having high knowledge about storage of grain Kubde et al (2000) given similar findings .35.00 per cent of the respondents were having low knowledge about spacing whereas 48.3 per cent of the respondents were having medium knowledge and 16.66 per cent of the respondents were having low knowledge about spacing. Majority (53.3\%) of the respondents were having medium knowledge about sowing time , 28.3 per cent having low and 18.3 per cent having high knowledge about sowing time. 44.1 per cent of the respondents were having medium knowledge about seed and its treatment ,27.5 per cent having high knowledge and 28.33 per cent of the respondents were having low knowledge about seed and its treatment. 32.5 per cent of the respondents were having high knowledge about improved variety whereas 42.5 per cent were having medium and 25.00 per cent were having low knowledge about improved variety. Vinod Gupta et. al (2001), Shinde (2002) given similar findings. Majority (55.00\%) of the respondents were having low knowledge about field preparation and 19.1 per cent of the respondents were having medium and 25.83 per cent of the respondents were high knowledge about field preparation. 45.83 per cent of the respondents were having 


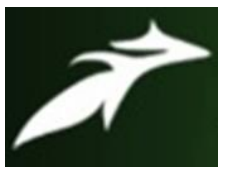

Awantika Rai et al, International Journal of Advances in Agricultural Science and Technology, Vol.8 Issue.1, January-2021, pg. 33-39

ISSN: 2348-1358

Impact Factor: 6.057

NAAS Rating: 3.77

medium knowledge about manure and fertilizers whereas 33.33 per cent of the respondents were having low and 20.83 per cent of the respondents were having high knowledge about manure and fertilizers Sathasivam et al, (2009) . Majority (54.16\%) of the respondents were having medium knowledge about irrigation whereas 25.00 per cent of the respondents were having low and 20.83 per cent of the respondents were having high knowledge about irriagation.48.33 per cent of the respondents were having medium knowledge about weeding and hoeing whereas 30.83 per cent were having low and and 18.33 per cent were having high knowledge about weeding and hoeing operations.29.16 per cent of the respondents were high knowledge about weed control and 45.8 were having medium and 16.66 per cent were having low knowledge about weed control. Majority $(52.5 \%)$ of the respondents were having medium knowledge about plant protection measure and 24.1 per cent low and 23.3 per cent high respectively. 49.16 per cent of the respondents were having medium knowledge about harvesting whereas 22.5 per cent low and 28.33 per cent of the respondents were having high knowledge about harvesting . 43.33 per cent of the respondents were having medium knowledge about threshing and winnowing , 34.16 per cent low and 22.5 per cent having high knowledge about threshing and winnowing.

Table-3: Over-all knowledge of the Respondents

\begin{tabular}{|c|l|l|l|}
\hline SR.NO. & \multicolumn{1}{|c|}{ Category } & \multicolumn{1}{|c|}{ Frequency } & \multicolumn{1}{c|}{ Percentage } \\
\hline 1 & Low & 38 & 31.66 \\
\hline 2 & Medium & 57 & 47.5 \\
\hline 3 & High & 25 & 20.33 \\
& & & \\
\hline
\end{tabular}

The above table represents that 47.5 per cent of the farmers were medium level of farmers, 31.66 per cent were low level of farmers and 20.33 per cent were high level of farmers.

Table- 4: Correlation between knowledge of farmers about improved production practices of Jowar with independent variables $(n=120)$

\begin{tabular}{|c|l|l|}
\hline SR.No. & \multicolumn{1}{|c|}{ Variables } & Correlation Coefficient \\
\hline 1 & Age & $0.035 \mathrm{NS}$ \\
\hline 2 & Education & $0.832^{* *}$ \\
\hline 3 & Family Size & $-0.107 \mathrm{NS}$ \\
\hline
\end{tabular}




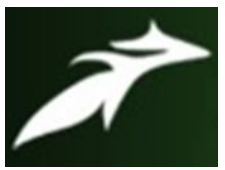

Awantika Rai et al, International Journal of Advances in Agricultural Science and Technology, Vol.8 Issue.1, January-2021, pg. 33-39

ISSN: 2348-1358

Impact Factor: 6.057

NAAS Rating: 3.77

\begin{tabular}{|c|l|l|}
\hline 4 & Annual Income & $0.403^{*}$ \\
\hline 5 & Land Holding & $0.584^{*}$ \\
\hline 6 & Social Participation & $0.160^{*}$ \\
\hline 7 & Market Orientation & $0.590^{*}$ \\
\hline 8 & Economic Motivation & $0.843^{* *}$ \\
\hline 10 & Farming Experience & $0.145^{*}$ \\
\hline 11 & Risk Orientation & $0.328^{*}$ \\
\hline
\end{tabular}

** Strongly significant, *moderate significant, NS non significant

\section{CONCLUSION}

It was concluded that the socio- economic profile of the respondents were medium level, it was also found that the knowledge level of the respondents were medium level because they have medium level of knowledge in their working of different activities. The most strong association of knowledge and socio- economic status were economic motivation, education, market orientation, and land holding were strongly correlated, it simply implies boosting these independent variables will simply improve the production. As these variables highly influenced our production practices.

\section{REFERENCES}

[1]. DAREKAR, N.P. 2002. A study on knowledge and adoption of recommended package of practices of Parbhani Turab. M.Sc.(Agri) Thesis, MAU, Parbhani.

[2]. KHARMALE, P.R 2000. Knowledge and adoption of vermicompost technology by the farmers. M.Sc . (Agri) Thesis, MAU, Parbhani.

[3]. KUBDE, V.R., BHOPLE, S.R. AND TEKLE,V.S., 2000, Knowledge and adoption of cultivation and storage practices of potato. Maharashtra Journal of Extension Education, 19:293-29.

[4]. SATHASIVAM, S. THYGARJAN AND PARTHASARATHI, S., 2009, Knowledge level of paddy growers about IPM Biofertilizers practices, Journal of Extension Education 21(1):4194-4196.

[5]. VINOD GUPTA, DILIP AND DUNDARSWAMY, B., 2001, Knowledge of the farmers about improved cultivation practices of Rice in Jammu, Maharashtra Journal of Extension Education, 20:74-76. 